nhóm cai thở máy đơn giản, và cai thở máy khó; đồng thời là gánh nặng cho chăm sóc lực y tế. Bệnh lý thần kinh cớ phải nhập viện thở máy là yếu tố nguy cơ cao cho cai thở máy kéo dài. RSBI và PaCO2 sau nghiệm pháp tự thở là yếu tố độc lập tiên lượng cho cai thở máy kéo dài.

\section{TÀI LIÊU THAM KHẢO}

1. Funk GC, Anders S, Breyer MK, Burghuber OC, Edelmann $\mathbf{G}$, Heindl $\mathbf{W}$, et al. Incidence and outcome of weaning from mechanical ventilation according to new categories. The European respiratory journal. 2010;35(1):88-94.

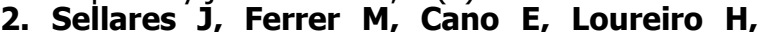
Valencia M, Torres A. Predictors of prolonged weaning and survival during ventilator weaning in a respiratory ICU. Intensive care medicine. 2011;37(5):775-84

3. Hamdy A. Mohammadien, Doaa G. Hassanin, Mona T. Hossien, Mostafa I. Ali. Predictors of prolonged weaning among mechanically ventilated patients in respiratory intensive care unit. Sohag medical journal. 2018; 22( 2):103-114

\title{
PHÂN TÍCH KẾT QUẢ LÂM SÀNG VÀ BIẾN CỐ BẤT LỢI TRÊN NGƯỜI BÊNH COVID-19 ĐƯợC SỬ DUNG THUỐC REMDESIVIR TẠI BÊ̂NH VIÊ̂N ĐA KHOA QUỐC TẾ VINMEC
}

\author{
Dương Thanh Hải ${ }^{1}$, Khổng Trọng Thắng ${ }^{2}$, Trương Ngọc Hải ${ }^{2}$, \\ Ngô Thị Thu Thủy ${ }^{2}$, Nguyễn Hoàng Phương Khanh ${ }^{2}$, Nguyễn Đỗ Quang Trung', \\ Lương Thị Hải Vân ${ }^{3}$, Nguyễn Lê Thùy Dung ${ }^{2}$, Lý Anh Thư ${ }^{2}$, \\ Bùi Hồng Ngọc ${ }^{2}$, Lê Quốc Sử ${ }^{2}$, Phan Quỳnh Lan ${ }^{1}$
}

\section{TÓM TẮT}

Remdesivir là thuốc kháng virus đã được chấp thuận trong điều trị bệnh nhân COVID-19 nhập viện ở nhiểu nước trên thế giới, trong đó có Viêt Nam. Tuy nhiên, hiện chưa có nghiên cứu nào về remdesivir được công bố tại Việt Nam. Chính vì thế, nghiên cứu được thực hiện để phân tích kết quả điều trị và độ an toàn của remdesivir trên bệnh nhân COVID-19 tai Viêt Nam. Nghiên cứu hồi cứu, mô tả thực hiện trên bệnh nhân COVID-19 từ 12 tuổi trở lên có chỉ định nhập viện và được điều trị với ít nhất một liêu remdesivir tử ngày 10/08/2021 đển ngày 10/09/2021 tại Bệnh viện đa khoa quốc tế Vinmec Central Park. Kết quả điều trị được đánh giá theo thang WHO 6 điểm, biến cố thở máy ngày 14 và tử vong tại thời điểm ngày 28 . Độ an toàn của remdesivir được đánh giá dựa trên tỷ lệ biến cố không mong muốn ghi nhận theo thang AIDS 2017.Kết quả: Nghiên cứu thu thập được 152 bệnh nhân COVID -19 được điêu trị bằng remdesivir, trong đó hơn $50 \%$ có ít nhất 1 bệnh lý nền, chủ yếu là bệnh lý tim mạch hoăcc đái tháo đường. Các bệnh nhân được dùng thuốc remdesivir trong vòng trung vị 6 ngày đâu khởi phát. Có $55,7 \%$ người bệnh cải thiện lâm sàng rõ rệt tại ngày thứ 11 so với trước khi dùng remdesivir. Chỉ có $14,6 \%$ bệnh nhân tiến triển nặng phải thở máy xâm nhập tính đến ngày thứ 14. Tỷ lệ tử vong ở ngày thứ 28 là 12,5\%. Các biến cố bất lợi được

${ }^{1}$ Bệnh viện đa khoa quốc tế Vinmec Times City

${ }^{2}$ Vinmec Central Park

${ }^{3}$ Vinmec Nha Trang

Chịu trách nhiệm chính: Phan Quỳnh Lan

Email: v.lanpq@vinmec.com

Ngày nhận bài: 18.10.2021

Ngày phản biên khoa học: 16.12.2021

Ngày duyệt bài: 24.12.2021 ghi nhận ở bệnh nhân dùng thuốc bao gồm tăng men gan $(29,6 \%)$, hạ kali $(26,3 \%)$, giảm độ lọc câu thận $(17,8 \%)$, chậm nhịp tim $(11,2 \%)$ và kéo dài thời gian prothrombin $(15,1 \%)$. Các yếu tố tiên lượng nặng lâm sàng bao gồm tuổi cao; mắc ít nhất một bệnh lý nền (COPD, tim mạch, đái tháo đường); người cần hỗ trợ thở oxy dòng cao HFNC, thở máy không xâm nhập hoặc thở máy xâm nhập;chỉ số ROX, tăng chỉ số viêm PCT, D-Dimer, ferritin; giảm số lượng bạch cầu lympho trước khi điều trị.

\section{SUMMARY}

\section{CLINICAL OUTCOMES AND SAFETY IN COVID -19 PATIENTS TREATED WITH REMDESIVIR IN VINMEC INTERNATIONAL HOSPITAL}

Remdesivir is an antiviral drug that has been approved for the treatment of hospitalized COVID-19 patients in many countries, including Vietnam. However, clinical data of remdesivir is lacking in Vietnam. This study was carried out to investigate clinical outcome and safety of remdesivir in the treatment of COVID-19 in Vietnam. A retrospective observational study was performed in all hospitalized COVID-19 patients 12 years of age and older treated with at least one dose of remdesivir from 10 August 2021 to 10 September 2021 at Vinmec Central Park Hospital. The clinical outcome was measured by the WHO 6-point scale, mechanical ventilation at day 14 , and 28-day mortality. The safety of remdesivir was evaluated based on the 2017 AIDS scale. Results: 152 patients were enrolled in this study with more than $50 \%$ had at least one comorbidity, mainly cardiovascular diseases or diabetes. Patients was treated with remdesivir at median 6 days after onset. $55.7 \%$ patients had significant clinical improvement at day 11 . In this study, $14.6 \%$ of patients received invasive mechanical ventilation on day 14 . The 28-day 
mortality was $12.5 \%$. The most commonly reported adverse events included elevation of liver enzymes $(29.6 \%)$, hypokalemia (26.3\%), decreased glomerular filtration rate $(17.8 \%)$, bradycardia $(11.2 \%)$ and prolongation of prothrombin time (15.1\%). Risk factor for poor outcome were advanced age, having at least one comorbidity, low ROX score, requirement of HFNC, non-invasive ventilation or invasive mechanical ventilation; elevated PCT, D-Dimer, ferritin; decreased lymphocyte count at baseline.

\section{I. ĐĂT VẤN ĐỀ}

Remdesevir là một trong những thuốc kháng virus có cấu trúc dẫn chất nucleotide (nucleotide analog) được phát triển để điều trị virus Ebola trước khi được nghiên cứu để điều trị Covid-19. Thuốc đã được cấp phép khẩn cấp và khuyến cáo tại nhiều nước trên thế giới để sử dụng cho bệnh nhân mắc Covid-19. Tháng 8 năm 2021, Bộ Y tế Việt Nam đã cấp phép và ban hành công văn số 6573/BYT-KCB hướng dẫn các cơ sở khám chữa bệnh về việc sử dụng remdesivir điều trị người bệnh Covid- 19 mức độ nặng có suy hô hấp phải thở oxy, thở HFNC, hoặc thở máy không xâm nhập. Đồng thời, Bộ y tế cũng yêu câu thực hiên theo dõi, đánh giá và báo cáo hiêu quả điều trị và an toàn của thuốc. Nghiên cứu được thực hiện nhằm:

- Mô tả kết quả điều trị và các biến cố bất lợi ở người bệnh được dùng remdesivir.

- Phân tích các yếu tố tiên lượng lâm sàng ở người bệnh Covid -19 được dùng thuốc remdesivir.

\section{II. Đốl TƯợNG VÀ PHƯƠNG PHÁP NGHIÊN CỨU}

- Nghiên cứu hồi cứu, mô tả.

- Đối tượng nghiên cứu: Tất cả người bệnh điều trị trong khoảng thời gian từ 10/8/2021 đến 10/9/2021 thỏa mãn tiêu chuẩn: từ 12 tuổi trở lên, chẩn đoán SARS-CoV-2 bằng xét nghiệm real-time PCR và được dùng ít nhất 1 liều remdesivir.

- Chỉ tiểu nghiên cứu

- Kết quả điêu trị:

- Tỷ lệ \% cải thiên lâm sàng ngày 11.Cải thiện lâm sàng được định nghĩa là giảm ít nhất 1 điểm trên thang WHO 6 điểm

- Tỷ lệ \% người bệnh phải thở máy tính đến thời điểm ngày 14.

- Tỷ lệ \% tử vong tính đến ngày 28

- Các biến cố bất lợi:

- Tỷ lệ \% ghi nhận các biến cố

- Mức độ nghiêm trong của biến cố phân loại hướng dẫn của Khoa AIDS - Viện Dị ứng và Bệnh nhiễm trùng Quốc gia Hoa Kỳ $2017^{8}$

- Tỷ lệ \% người bệnh phải ngừng thuốc vì các biến cố.

- Phân tích các yếu tố tiên lượng lâm sàng, bao gồm: thời gian từ lúc khởi phát triệu chứng đến khi dùng thuốc, mắc ít nhất một bệnh lý nền làm tăng nguy cơ tiến triển nặng, tuổi, BMI, tiền sử tiêm vaccine Covid-19 và tình trạng nặng trước khi dùng thuốc.

- Xử lý dữ liệu: Thống kê mô tả, biến liên tục phân bố chuẩn biểu diễn bằng trung bình \pm độ lệch chuẩn, biến không phân bố chuẩn được biểu diễn bằng trung vị, tứ phân vị. So sánh biến liên tục bằng Wilcoxon test, biến phân hạng bằng Fisher's exact test. Phân tích hồi quy logistic được dùng để phân tích các yễu tố tiên lượng.

\section{KẾT QUẢ NGHIÊN CỨU}

1. Đăcc điểm mẫu nghiên cứu. Nghiên cứu thu thập được 152 người bệnh sử dụng thuốc remdesivir. Đặc điểm người bệnh trước khi dùng remdesivir được trình bày trong bảng 1 .

Bảng 1. Đặc điểm người bệnh trước khi dùng thuốc

\begin{tabular}{|c|c|}
\hline Tiêu chí & Kết quả $(\mathrm{N}=152)$ \\
\hline Tuối (năm) (trung vị, tứ phân vị) & $61(44-70)$ \\
\hline Nam giới $(n, \%)$ & $77(50,7 \%)$ \\
\hline Phụ nữ có thai $(n, \%)$ & $3(2 \%)$ \\
\hline Cân nặng (kg) (trung vị, tứ phân vị) & $62(55-70)$ \\
\hline BMI (trung vị, tứ phân vị) & $24.3(21.6-26.6)$ \\
\hline BMI $\geq 30(n, \%)$ & $11(7,2 \%)$ \\
\hline \multicolumn{2}{|l|}{ Số lượng bệnh mằc kèm $(\mathrm{n}, \%)$} \\
\hline 1 bệnh & $56(36,8 \%)$ \\
\hline$\geq 2$ bệnh & $32(21,1 \%)$ \\
\hline \multicolumn{2}{|l|}{ Tiền sử tiêm vaccin Covid $-19(\mathbf{N}=148)$} \\
\hline Chưa tiêm $(n, \%)$ & $52(35,1 \%)$ \\
\hline Tiêm 1 mũi $(n, \%)$ & $90(60,8 \%)$ \\
\hline Tiêm 2 mũi $(\mathrm{n}, \%)$ & $6(4,1 \%)$ \\
\hline $\begin{array}{l}\text { Số ngày khởi phát triệu chứng trước khi điều trị Remdesivir } \\
\qquad(\mathbf{N}=\mathbf{1 5 0}) \text { (trung vị, tứ phân vị) }\end{array}$ & $6(4-8)$ \\
\hline
\end{tabular}




\begin{tabular}{|c|c|}
\hline Tải lượng virus (CT) N=148 (trung vị, tứ phân vị) & $26(22-30)$ \\
\hline eGFR - ml/phút ( $\mathbf{N}=136)$ (trung vị, tứ phân vị) & $73,2(54,0-88,5)$ \\
\hline ALT $(I U / L)(\mathbf{N}=136)$ (trung vị, tứ phần vị) & $43,1(24,3-70,8)$ \\
\hline AST (IU/L) (N=136) (trung vị, tứ phân vị) & $48,5(29,7-74,6)$ \\
\hline \multicolumn{2}{|l|}{ Các chỉ số xét nghiệm đánh giá mức độ bệnh } \\
\hline Giảm BC lympho < $1 \mathrm{G} / \mathrm{L}(\mathrm{N}=139)(\mathrm{n}, \%)$ & $85(61,2 \%)$ \\
\hline Tăng CRP $>10 \mathrm{mg} / \mathrm{ml}(\mathrm{N}=136)(\mathrm{n}, \%)$ & $39(28,7 \%)$ \\
\hline Tăng PCT > $0.5 \mu \mathrm{g} / \mathrm{L}(\mathrm{N}=80)(\mathrm{n}, \%)$ & $14(17,5 \%)$ \\
\hline Tăng D-Dimer > $1000 \mu \mathrm{g} / \mathrm{L}(\mathrm{N}=134)(\mathrm{n}, \%)$ & $41(30,6 \%)$ \\
\hline Ferritin $>500 \mu \mathrm{g} / \mathrm{L}(\mathrm{N}=127)(\mathrm{n}, \%)$ & $78(61,4 \%)$ \\
\hline Tăng LDH > $300 \mathrm{U} / \mathrm{L}(\mathrm{N}=124)$ & $67(54 \%)$ \\
\hline Tăng IL - $6(>7 n g / L)(N=17)(n, \%)$ & $14(82,3 \%)$ \\
\hline Điếm lâm sàng theo thang WHO (trung vị, tứ phân vị) & $3(2-3)$ \\
\hline 2: nhập viện không cần thở oxy $(n, \%)$ & $46(30,3 \%)$ \\
\hline 3: cần hồ trợ thở oxy liều thấp (n, \%) & $77(50,7 \%)$ \\
\hline 4: HFNC hoặc thở không xâm nhập (n, \%) & $24(15,8 \%)$ \\
\hline 5: thơ máy xâm nhâp hoăc ECMO $(n, \%)$ & $5(3,3 \%)$ \\
\hline
\end{tabular}

Người bệnh trong nghiên cứu có độ tuổi từ 12 theo khuyến cáo, chủ yếu là 5 ngày. Thuốc - 90 tuổi, với hơn $50 \%$ có ít nhất 1 bệnh lý nền, chống đông, corticosteroid và kháng sinh là 3 chủ yếu là bệnh lý tim mạch (tăng huyết áp, suy nhóm thuốc được sử dụng phổ biến đồng thời tim) hoặc đái tháo đường. 7,2\% người bệnh có cùng với thuốc kháng virus remdesivir. Có $25,6 \%$ béo phì BMI > $30 \mathrm{~kg} / \mathrm{m}^{2}$. Khoảng $65 \%$ người người bệnh được dùng corticoid liều pulse.

bệnh đã được tiêm ít nhất 1 mũi vaccine, chỉ $\quad$ 2. Mô tả kết quả điêu trị và biến cố ở $4,1 \%$ tiêm đủ 2 mũi. Hầu hết người bệnh trong nghiên cứu đều được dùng thuốc trong vòng 10 ngày sau khi khởi phát triệu chứng, chỉ có $7,3 \%$ dùng thuốc sau 10 ngày khởi phát. Có $87,5 \%$ người bệnh được dùng remdesivir từ 5 - 10 ngày

\section{người bênh được điều trị remdesivir}

2.1 Kêt quả điều trị. Kết quả điều trị của người bệnh dùng thuốc remdesivir được mô tả trong bảng 2.

Bảng 2: Kêt quả điều trị thu được trong nghiên cứu

\begin{tabular}{|c|c|}
\hline Tiêu chí & Kết quả \\
\hline Điếm lâm sàng ngày 11, $\mathbf{N}=149$ (trung vi, tứ phân vi) & $2(1-4)$ \\
\hline Điếm lâm sàng ngày 28 / xuất viện $\mathbf{N}=144$ (trung vị, tứ phân vị) & $1(1-1)$ \\
\hline Cải thiện lâm sàng ngày $\mathbf{1 1}^{\mathrm{a}} \mathbf{N}=149(\mathrm{n}, \%)$ & $83(55,7 \%)$ \\
\hline Thở máy tính đến thời điểm ngày $14 \mathbf{N}=149(\mathrm{n}, \%)$ & $22(14,8 \%)$ \\
\hline Cải thiện lâm sàng ngày $\mathbf{2 8}^{\mathbf{a}} \mathbf{N}=144(\mathrm{n}, \%)$ & $106(73,6 \%)$ \\
\hline Tứ vong ngày $28, \mathbf{N}=144(\mathrm{n}, \%)$ & $18(12,5 \%)$ \\
\hline Số ngày nằm viện, $\mathbf{N}=\mathbf{1 3 8}$ ( $n$, trung vị, tứ phân vị) & $12(8-15,25)$ \\
\hline
\end{tabular}

a: cải thiện lâm sàng: giảm ít nhất 1 điểm theo thang WHO 6 điểm.

Đánh giá mức độ cải thiện lâm sàng theo thang 6 điểm WHO, chúng tôi ghi nhận cải thiện lâm sàng rõ rệt tại thời điểm ngày 11 so với thời điểm trước khi dùng thuốc (so sánh bằng kiểm định Wilcoxon, $Z=-4,116, P<0,0001$ ). Mức độ cải thiện lâm sàng ngày thứ 11 và tỷ lệ tử vong ngày 28 ở các nhóm bệnh nhân theo nhu cầu hỗ trợ oxy ban đầu được mô tả trong hình 1 .

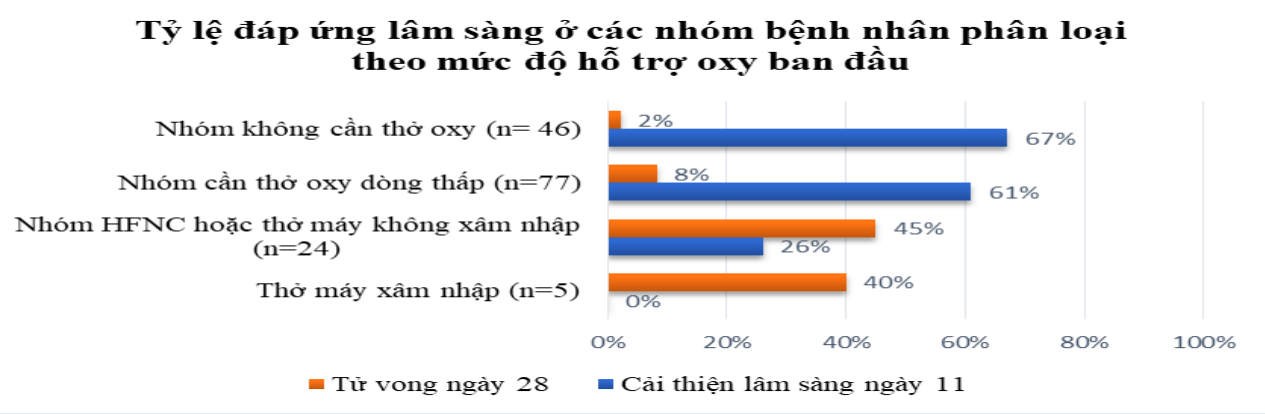

Hình 1: Tỷ lệ cải thiện lâm sàng ngày 11 và tử vong ngày 28 theo các nhóm người bệnh 


\subsection{Mô tả các biến cố xảy ra trên người bệnh dùng thuốc}

Các biến cố ghi nhận trong nghiên cứu được trình bày trong bảng 3 .

Bảng 3: Tỷ lệ \% người bệnh gặp các biến cố ghi nhận trong nghiên cứu

\begin{tabular}{|c|c|c|c|}
\hline Tiêu chí & $\begin{array}{l}\text { Kết quả } \\
(\mathrm{N}=152)\end{array}$ & Tiêu chí & $\begin{array}{c}\text { Kết quả } \\
(\mathbf{N}=152)\end{array}$ \\
\hline Giảm mức lọc câu thận $(n, \%)$ & $27(17,8 \%)$ & Hạ kali máu (n, \%) & $40(26,3 \%)$ \\
\hline Mức 2 & $14(9,2 \%)$ & Mức 1 & $26(17,1 \%)$ \\
\hline Mức 3 & $6(3,9 \%)$ & Mức 2 & $13(8,6 \%)$ \\
\hline Mức 4 & $7(4,6 \%)$ & Mức 3 & $1(0,7 \%)$ \\
\hline Tăng men gan $(n, \%)$ & $45(29,6 \%)$ & Kéo dài PT $(n, \%)$ & $22(15,1 \%)$ \\
\hline Mức 1 & $28(18,4 \%)$ & Mức 1 & $8(5,3 \%)$ \\
\hline Mức 2 & $11(7,2 \%)$ & Mức 2 & $9(5,3 \%)$ \\
\hline Mức 3 & $2(1,3 \%)$ & Mức 3 & $6(3,9 \%)$ \\
\hline Mức 4 & $4(2,6 \%)$ & Quá mân $(n, \%)$ & $1(0,7 \%)$ \\
\hline Chậm nhịp tim (n, \%) & $17(11,2 \%)$ & Mức 2 & $1(0,7 \%)$ \\
\hline Mức 1 & $14(9,2 \%)$ & $\begin{array}{c}\text { Ngừng remdesivir do } \\
\text { tác dụng phụ }\end{array}$ & $\begin{array}{c}1 \\
\text { (tăng men gan) }\end{array}$ \\
\hline Hạ huyết áp $(\mathrm{n}, \%)$ & $5(3,3 \%)$ & & \\
\hline
\end{tabular}

Biến cố tăng men gan gặp ở 29,6\%, trong đó $19,6 \%$ có tăng men gan trước khi sử dụng thuốc. Chỉ có $10 \%$ xảy ra sau khi dùng thuốc. Tỷ lệ BN tăng men gan mức 3 hoăc 4 là $3,9 \%$. Chỉ có duy nhất 1 trường hợp phải ngừng thuốc do tăng men gan trên 10 lần giới hạn bình thường. Hạ kali máu chủ yếu gặp ở mức nhẹ $3-3,4 \mathrm{mEq} / \mathrm{L}$ ).

3. Phân tích các yếu tố tiên lượng lâm sàng. Phân tích hồi quy logistic đơn biến trên 2 nhóm người bệnh sống sót và nhóm tử von, kết quả như sau:

Bảng 4: Yếu tố nguy cơ giữa 2 nhóm tử vong và sống sót thời điểm ngày 28

\begin{tabular}{|c|c|c|c|c|}
\hline & $\begin{array}{l}\text { Nhóm tử vong } \\
(\mathbf{N}=18)\end{array}$ & $\begin{array}{l}\text { Nhóm sống sót } \\
(\mathrm{N}=126)\end{array}$ & $\begin{array}{c}\text { OR } \\
\text { (CI } 95 \%)\end{array}$ & $\mathbf{P}$ \\
\hline Tuối (trung vị, tứ phân vị) & $70,5(64-76)$ & $58(40,75-68)$ & $\mathbf{1}, \mathbf{0 6}(1,02-1,1)$ & $\mathbf{0 , 0 0 3}$ \\
\hline Giới tính nam $(\mathrm{n}, \%)$ & $10(55,6 \%)$ & $64(50,8 \%)$ & $1,21(0,44-3,26)$ & \\
\hline $\begin{array}{c}\mathrm{BMI} \mathrm{kg} / \mathrm{m}^{2} \\
\text { (trung vị, tứ phân vị) }\end{array}$ & $\begin{array}{c}23,9 \\
(22,0-27,5)\end{array}$ & $\begin{array}{c}24,3 \\
(22,1-26,7)\end{array}$ & $\begin{array}{c}0,99 \\
\left(0,87^{-1,14)}\right.\end{array}$ & 0,979 \\
\hline $\begin{array}{l}\text { Thời gian từ lúc khởi phát triệu } \\
\text { chứng bệnh trước khi dùng } \\
\text { thuốc (ngày) }\end{array}$ & $\begin{array}{c}7 \\
(4-9,5)\end{array}$ & $(4-8)$ & $\begin{array}{c}1,04 \\
\left(0,89^{-1}, 21\right)\end{array}$ & 0,588 \\
\hline $\begin{array}{c}\text { Măc } \geq 1 \text { bệnh lý nền tăng } \\
\text { nguy cơ }\end{array}$ & $14(77,8 \%)$ & $66(52,4 \%)$ & $\begin{array}{c}\mathbf{3 , 1 8} \\
(0,99-10,2)\end{array}$ & 0,051 \\
\hline Số bệnh & $1(0,75-1,25)$ & $1(0-1)$ & $1,45(0,79-2,63)$ & 0,227 \\
\hline Sốc nh & $1(5,6 \%)$ & 0 & $4 \times 10^{7}$ & 0,99 \\
\hline $\begin{array}{l}\text { Chưa tiêm vaccin COVID } \\
\text { Tiêm đủ } 2 \text { mũi }\end{array}$ & $\begin{array}{c}8(44,4 \%) \\
0\end{array}$ & $\begin{array}{c}42(34,4 \%) \\
6(4,9 \%)\end{array}$ & $\begin{array}{c}1,52(0,56-4,1) \\
0\end{array}$ & $\begin{array}{r}0,41 \\
0,992\end{array}$ \\
\hline \multicolumn{5}{|c|}{ Tình trạng hô trợ hô hấp trước khi điều trị remdesivir } \\
\hline 3: oxy liều thấp $(n, \%)$ & $5(27,8 \%)$ & $66(52,4 \%)$ & $4,04(0,46-34,6)$ & 0,204 \\
\hline $\begin{array}{c}\text { 4: HFNC hoắc thở không xâm } \\
\text { nhập }(n, \%)\end{array}$ & $9(50,0 \%)$ & $11(8,7 \%)$ & $\begin{array}{c}36,8 \\
(4,2-322,0)\end{array}$ & $<0,001$ \\
\hline $\begin{array}{l}\text { 5: thở máy xâm nhập hoặc } \\
\operatorname{ECMO~}(n, \%)\end{array}$ & $2(11,1 \%)$ & $3(2,4 \%)$ & $\begin{array}{c}30 \\
(2,07-433,12)\end{array}$ & 0,013 \\
\hline ROX score $(\mathrm{t}$ & $9,6(4,6-13,9)$ & $20,5(12,9-23,1)$ & $0,85(0,78-0,92)$ & $<0,001$ \\
\hline Tăng Cl & $30(26 \%)$ & $16(43,7 \%$ & $2,2(0,75-6,46)$ & 0.14 \\
\hline Tăng PC & $6(46,1 \%)$ & & $8(2,01-31,7)$ & \\
\hline Ferritin $>500 \mu \mathrm{g} / \mathrm{L}$ & $14(87,5 \%)$ & $61(58,1 \%)$ & $5,05(1,09-23,35)$ & 0,038 \\
\hline D- Dime & & $27(24,1 \%)$ & $6,93(2,2-21,7)$ & $<0,001$ \\
\hline $\mathrm{G} / \mathrm{L}$ & $14(82,4 \%)$ & $65(56,0 \%)$ & $3,66(0,99-13,42)$ & 0,05 \\
\hline Tăng LDH >300 U/L & $14(100 \%)$ & $48(46,2 \%)$ & $4 \times 10^{8}$ & 0,99 \\
\hline iếm số bão cyto & & $37(32,2 \%)$ & & 0,008 \\
\hline Số ngày dùng $\mathrm{R}$ & $5(5-5,25)$ & $5(5-5)$ & & 0,086 \\
\hline
\end{tabular}


Các yếu tố làm tăng nguy cơ tử vong ngày 28 $(p<0.05)$ bao gồm tuổi cao, mắc ít nhất 1 bệnh lý nền như đái tháo đường, tim mạch hoặc COPD, người bênh đã phải hố trợ thở HFNC thở máy không xâm nhập hoặc thở máy xâm nhập trước khi điều trị remdesivir, tăng các chỉ số viêm. Đáng lưu ý, nhóm người bệnh đã phải thở HFNC, thở máy không xâm nhập hoặc thở máy xâm nhập có nguy cơ tử vong cao hớn rất nhiều lần. Trên nhóm này, việc sử dụng remdesivir có thể không mang lại được lợi ích cải thiện tử vong.

\section{BÀN LUÂ̂N}

Remdesivir được dùng ở tất cả các giai đoạn nặng của bệnh, trong đó 46 người bệnh $(30,3 \%)$ không cần hố trợ thở oxy và 5 người bệnh $(3,3 \%)$ đã có thở máy xâm nhập/ECMO được chỉ định dùng thuốc. Trong số 46 người bệnh không cần hỗ trợ thở oxy, 74\% có ít nhất 1 trong các yếu tố nguy cơ cao tiến triển nặng bao gồm: tuổi cao (> 65 tuổi), BMI $\geq 25$, mắc bệnh lý nền làm tăng nguy cơ tiến triển nặng hoặc phụ nữ mang thai. Kết quả nghiên cứu ghi nhận cải thiện lâm sàng rõ rệt tại thời điểm ngày 11 so với thời điểm trước khi dùng thuốc, đặc biệt nhóm bệnh nhân chưa cân hỗ trợ thở oxy hoặc thở oxy dòng thấp. Tỷ lệ tử vong trong nghiên cứu của chúng tôi tương đồng với tỷ lệ tử vong ở người bệnh nhập viện do Covid 19 tại Mỹ dao động từ 9,319,7\%. Riêng đối với nhóm bệnh nhân được dùng Remdesivir theo các nghiên cứu, tỷ lệ dao động khoảng $8-14 \%^{2}$. Tỷ lệ \% người bệnh tiến triển thở máy xâm nhập đến ngày thứ 14 sau điêu trị remdesivir là $14,8 \%$. Con số này tương đồng với nghiên cứu Discovery là $15 \%{ }^{4}$

Tỷ lệ tử vong ngày 28 trên 2475 bệnh nhân không hỗ trợ thông khí cơ học, không được dùng remdesivir trong nghiên cứu Solidarity là $11 \%{ }^{1}$. Tương tự, nghiên cứu Recovery trên nhóm điều trị thông thường, tỷ lệ tử vong của nhóm bệnh nhân không cần hố trợ oxy là $14 \%{ }^{4}$. Như vậy, trong nghiên cứu của chúng tôi, tỷ lệ tử vong trên nhóm bệnh nhân này thấp hơn đáng kể, kết quả này gợi ý viễ̂c dùng thuốc sớm ở các bệnh nhân chưa cần hổ trợ oxy có thể mang lại lợi ích cải thiện tử vong cho người bệnh, đặc biệt trên các bệnh nhân có nguy cơ cao tiến triển nặng. Nghiên cứu cũng cho thấy, người bệnh thở HFNC, thở máy có nguy cơ tử vong cao hơn rất nhiều lần. Kết quả này cũng tương đồng với nghiên cứu $\mathrm{ACTT1}$ và Discovery, trên nhóm bệnh nhân này, lợi ích lâm sàng không khác biệt giữa có và khồng dùng remdesiviir ${ }^{3,4}$. Sử dụng remdesivir có thể không mang lại được lợi ích cải thiện tử vong ở nhóm này.

Có $60 \%$ người bệnh dùng remdesivir gặp phải ít nhất 1 biến cố, tương tự với báo cáo ở các nghiên cứu trước đó là từ $57-66 \%{ }^{6}$. Biến cố ghi nhận nhiều nhất là tăng men gan, hạ kali, giảm mức lọc câuu thận, chậm nhịp tim và kéo dài thời gian prothrombin. Tuy nhiên đây cũng là các triệu chứng của bệnh Covid 19, chỉ có 1 trường hợp phải ngừng thuốc liên quan đến biến cố tăng men gan. Chậm nhịp tim chiếm tỷ lệ $11,2 \%$, trong đó, $50 \%$ gặp biến cố này sau khi đã ngưng remdesivir, có 3 bệnh nhân $(1,9 \%)$ chúng tôi đánh giá chậm nhịp tim có khả năng do thuốc. Kéo dài thời gian thrombin là một trong các tác dụng không mong muốn được ghi nhận khi sử dụng remdesivir, tuy nhiên $92 \%$ người bệnh dùng kèm thuốc chống đông, là yếu tố gây ảnh hưởng đến kết quả này.

Nghiên cứu đã mô tả được những kết quả điều trị và biến cố xảy ra ở nhóm người bệnh Covid 19 được dùng thuốc remdesivir. Nghiên cứu cũng ghi nhận các yếu tố có thể ảnh hưởng đến kết cục điều trị. Tuy nhiên, do không có nhóm chứng, chúng tôi không thể kết luận được hiệu quả của thuốc cũng như xác định được nguy cơ làm tăng các biến cố do thuốc. Ngoài ra, nghiên cứu chưa thực hiện được trên cỡ mẫu đủ lớn để xây dựng được mô hình tiên lượng tử vong ở người bệnh dùng thuốc. Cần có thêm nghiên cứu quy mô lớn hơn để xác định được lợi ích của thuốc trên từng nhóm người bệnh.

\section{KẾT LUẦN}

Nghiên cứu thu thập được 152 người, hầu hết được dùng thuốc remdesivir trong vòng 10 ngày sau khi khởi phát triệu chứng. Remdesivir được dùng ở tất cả các giai đoạn nặng của bệnh, tập trung chủ yếu ở nhóm chưa cần hỗ trợ thở oxy hoặc hỗ trợ oxy liều thấp.Thuốc được dung nạp tốt. Cải thiện lâm sàng được ghi nhận rõ rệt tại thời điểm ngày thứ 11 , với $55,7 \%$ cải thiện ít nhất 1 điểm trên thang WHO 6 điểm. Tỷ lệ \% người bệnh tiến triển thở máy xâm nhập đến ngày thứ 14 sau điều trị remdesivir là $14,8 \%$ và tỷ lệ tử vong ngày 28 là 12,5\%. Tỷ lệ biến cố ghi nhận nhiều nhất trong nhóm bệnh nhân nghiên cứu là tăng men gan, hạ kali, giảm mức lọc cầu thận, chậm nhịp tim và kéo dài thời gian prothrombin.

\section{TÀI LIÊU THAM KHẢO}

1. WHO Solidarity Trial Consortium, Pan H, Peto R, et al. Repurposed Antiviral Drugs for Covid-19 - Interim WHO Solidarity Trial Results. N Engl J Med. 2021;384(6):497-511. 
doi:10.1056/NEJMoa2023184

2. Bansal V, Mahapure KS, Bhurwal A, et al. Mortality Benefit of Remdesivir in COVID-19: A Systematic Review and Meta-Analysis. Front Med. 2021;7:606429. doi:10.3389/fmed.2020.606429

3. Ader F, Bouscambert-Duchamp M, Hites M, et al. Remdesivir plus standard of care versus standard of care alone for the treatment of patients admitted to hospital with COVID-19 (DisCoVeRy): a phase 3, randomised, controlled, open-label trial. Lancet Infect Dis. Published online September 14, 2021. doi:10.1016/S14733099(21)00485-0

4. Beigel JH, Tomashek KM, Dodd LE, et al. Remdesivir for the Treatment of Covid-19 - Final Report. N Engl J Med. 2020;383(19):1813-1826. doi:10.1056/NEJMoa2007764

5. Spinner CD, Gottlieb RL, Criner GJ, et al. Effect of Remdesivir vs Standard Care on Clinical
Status at 11 Days in Patients With Moderate COVID-19: A Randomized Clinical Trial. JAMA. 2020;324(11):1048-1057. doi:10.1001/jama.2020.16349

6. Singh A, Kamath A. Assessment of adverse events associated with remdesivir use for coronavirus disease 2019 using real-world data. Expert Opin Drug Saf. Published online August 5, 2021:1-6. doi:10.1080/14740338.2021.1962846

7. RECOVERY Collaborative Group et al. "Dexamethasone in Hospitalized Patients with Covid-19." The New England journal of medicine vol. 384,8 (2021): 693-704.

8. U.S. Department of Health and Human Services, National Institutes of Health, National Institute of Allergy and Infectious Diseases, Division of AIDS. Division of AIDS (DAIDS) Table for Grading the Severity of Adult and Pediatric Adverse Events, Corrected Version 2.1. (2017).

\section{KHẢO SÁT ĐĂC ĐIỂM GIẢI PHẪU, BIẾN THỂ CỦA ĐỘNG MACH TUYẾN TIỀN LIẸTT TRÊN CHỤP CẮT LỚP VI TÍNH ĐA DÃY}

\section{TÓM TẮT}

Mục tiêu: Mô tả đặc điểm giải phẫu, biến thể của động mạch tuyến tiền liệt (BMTTL) trên chụp cắt lớp vi tính đa dãy (MSCT). Đối tượng và phương pháp: Nghiên cứu tiến cứu mô tả. Khảo sát phim chụp MSCT của $52 \mathrm{BN}$ phì đại lành tính tuyến tiền liệt (PĐLLTTL) tại Bệnh viện Quân y 103 từ tháng 9/2019 đến tháng 5/2021. Kểt quả: Trong nhóm nghiên cứu, tỷ lê tìm được 02 ĐMTTL rất hiểm, chỉ có 06/104 bên khung chẩu, chiếm tỷ lệ $5,8 \%$. Về vị trí xuất phát, type hay gặp nhất là động mạch TTL tách ra từ động mach then trong, chiếm $58,2 \%$. Hiếm găp nhất là đồng mạch TTL tách ra từ nhánh trước động mạch chậu trong, chiếm 1,8\%. Đường kính trung bình của động mạch TTL là $1,26 \pm 0,28 \mathrm{~mm}$. Hình dang xoắn của động mạch TTL chiếm tỳ lệ $50 \%$. Tỷ lệ quan sát được xơ vữa động mạch TTL là $28,2 \%$. Có $30 / 110$ tổng số trường hợp quan sát được vòng nối của động mạch $\Pi T L$, chiếm tỳ lệ $27,3 \%$. Kết luận: Cần nắm vững giải phẫu và biến thể của ĐMTTL khi điều trị bệnh lý TTL bằng can thiêp nội mạch. đa dãy

Tư khóa: động mạch tuyến tiền liệt, cắt lớp vi tính

\section{SUMMARY \\ SURVEY ON ANATOMICAL CHARACTERISTICS AND VARIANTS OF}

*Bệnh viện Quân y 103

Chịu trách nhiệm chính: Ngô Tuấn Minh

Email: ngotuanminh103hospital@gmail.com

Ngày nhận bài: 19.10.2021

Ngày phản biện khoa học: 16.12.2021

Ngày duyệt bài: 24.12.2021
Nguyễn Xuân Khái*, Ngô Tuấn Minh* PROSTATIC ARTERY ON MULTISLICE COMPUTED TOMOGRAPHY

Objectives: to describe anatomical characteristics and variants of prostatic artery on multislice computed tomography. Subjects and Methods: descriptive statistic study. Reviewing 54 the MSCT images of benign prostate plasia patient. Results: the rate of finding 02 prostate arteries was very rare, only 06/104 sides of the pelvis, accounting for $5.8 \%$. The most common type is the prostatic artery that separates from the internal pudendal artery, accounting for $58.2 \%$. The most rare is the prostatic artery separating from the anterior branch of the internal iliac artery, accounting for $1.8 \%$. The mean diameter of the prostatic artery was $1.26 \pm 0.28 \mathrm{~mm}$. The torsion shape of the prostate artery is found in 55/110 cases, accounting for $50 \%$. The observed rate of prostate atherosclerosis was $28.2 \%$. There were $30 / 110$ total cases where the prostatic artery junction was observed, accounting for $27.3 \%$. Conclusions: Profound knowledge of PA anatomy and variants on MSCT is necessary to treat prostate diseases by prostatic arterial embolization.

Keywords: prostate artery, multislice computed tomography

\section{I. ĐĂT VẤN ĐỀ}

Tuyến tiền liệt là một phần của hệ thống sinh dục nam giới có chức năng chính của tuyến tiền liệt là tạo dịch cho tinh dịch. Nút động mạch tiền liệt tuyến để điều trị phì đại lành tính tuyến tiền liệt ngày nay được triển khai rộng rãi trên thế giới cũng như tại Việt Nam. Tuy nhiên động mạch tuyến tiền liệt có đường kính khoảng 1$2 \mathrm{~mm}$ [1] và có nhiều biến thể phức tạp nên việc 